\title{
Stabilising cooperation through pragmatic tolerance: the case of the Parties to the Nauru Agreement (PNA) tuna fishery
}

\author{
Agnes David Yeeting ${ }^{1,2} \cdot$ Hans-Peter Weikard ${ }^{3} \cdot$ Megan Bailey $^{4} \cdot$ Vina Ram-Bidesi $^{5}$. \\ Simon R. Bush ${ }^{6}$
}

Received: 10 June 2016 / Accepted: 31 August 2017 /Published online: 11 November 2017

(C) The Author(s) 2017. This article is an open access publication

\begin{abstract}
Purse seine fishing of skipjack tuna in the Western and Central Pacific Ocean (WCPO) raises concern over increasing impacts on yellowfin and bigeye tuna by-catch. To address sustainability concerns, the Parties to the Nauru Agreement (PNA) adopted the vessel day scheme (VDS) for the management of purse seine fishing in the WCPO. The VDS has the potential to improve economic benefits for PNA members and to contribute to sustainability of the tuna stocks, and since 2012, has become an important mechanism to regulate fishing access rights in PNA waters. Despite this, monitoring and enforcement remains weak leading to violations of the agreement. Using a game theoretic framework, this paper examines the effectiveness of the VDS and its implications for fisheries regionalism. We examine the payoffs of member countries of the Nauru Agreement under full compliance and payoffs under the currently observed partial compliance. Our findings indicate that member states' partial compliance with
\end{abstract}

Editor:Diana Sietz

Electronic supplementary material The online version of this article (https://doi.org/10.1007/s10113-017-1219-0) contains supplementary material, which is available to authorized users.

Agnes David Yeeting

agnes.yeeting@usp.ac.fj; agnes.yeeting@wur.nl

Hans-Peter Weikard

hans-peter.weikard@wur.nl

Megan Bailey

Megan.Bailey@dal.ca

Vina Ram-Bidesi

vinarambidesi@gmail.com

Simon R. Bush

simon.bush@wur.nl
VDS rules plays a role in stabilising the agreement. Requiring full compliance, on the other hand, may encompass strong incentives for PNA members to deviate from the VDS since third parties offer attractive benefits in return for privileged access to fishing grounds. However, pragmatic tolerance of deviations from full VDS compliance seems to play a facilitative role in promoting cooperation and fisheries regionalism.

Keywords Fisheries regionalism - Tuna management · International fisheries agreements $\cdot$ RFMOs $\cdot$ Economic instruments $\cdot$ Compliance $\cdot$ Coalition stability

\section{Introduction}

Regionalism, or the development of shared processes and structures between geographically proximate states (Gochhayat
1 Department of Social Sciences, Environmental Policy Group, Wageningen University, Wageningen, Netherlands

2 School of Marine Studies, University of the South Pacific, Suva, Fiji

3 Department of Social Sciences, Environmental Economics and Natural Resources, Wageningen University, Wageningen, Netherlands

4 Marine Affairs Program, Faculty of Science, Dalhousie University, Halifax, Canada

5 School of Marine Studies, Faculty of Science, Technology \& Environment, University of the South Pacific, Suva, Fiji

6 Department of Social Sciences, Environmental Policy Group, Wageningen University, Wageningen, Netherlands 
2014; Miller et al. 2014), gained prominence in the management of transboundary fisheries in the 1970s in response to increasing depletion of the world's fisheries resources (Tsamenyi et al. 2001). Today, fisheries regionalism involves cooperation among states to develop policies, mobilise resources and execute relevant activities with appropriate degrees of integration (Hughes 2005; Hegland et al. 2012). In complex environmental and political 'seascapes' like the Western and Central Pacific Ocean (WCPO), regional and sub-regional organisations have become the cornerstone of economic and social development of Pacific Island states, strengthening their position in the international policy arena that addresses trade, conflicts and transboundary marine resources such as tuna.

The Western and Central Pacific Fisheries Commission (WCPFC), established in 2004, is responsible for managing straddling and highly migratory fish stocks in the WCPO (Tsamenyi et al. 2004), a region that accounts for approximately $60 \%$ of annual global tuna production (Harley et al. 2014). However, the effectiveness of the WCPFC to achieve sustainable management of tuna stocks is challenged by the dynamic and diverging interests of Pacific Island member states and those of distant water fishing nations (DWFNs), including access and foreign aid agreements with the United States (US) and the European Union (EU) (Langley et al. 2009; Hanich et al. 2010; Bailey et al. 2013). Amidst these interests, the WCPFC is tasked with maintaining the healthy status of the purse seine fishery for skipjack tuna while establishing conservation and management measures for non-target yellowfin and bigeye tuna stocks (Harley et al. 2014). Additionally, the Commission needs to consider demands of Pacific Island nations to increase harvesting of skipjack tuna, of which they receive only 3-6\% of the total landed value but that value contributes up to $10-40 \%$ of their GDP (Aqorau 2006; Havice 2010).

Predating the WCPFC is the 1982 sub-regional Nauru Agreement instituted to promote the equitable and sustainable use of tuna with the WCPO. The eight Parties to the Nauru Agreement (PNA) include the Federated States of Micronesia (FSM), Kiribati, Marshall Islands, Nauru, Palau, Papua New Guinea (PNG), Solomon Islands and Tuvalu (see Fig. 1). About $80 \%$ of the skipjack tuna caught in the WCPO is sourced from their waters, making them heavily dependent on the resource (Aqorau 2009; Harley et al. 2015). In 2007, the PNA countries adopted a vessel day scheme (VDS) and implemented it in 2012 under the Palau Agreement, with the aim of improving control and management of the skipjack purse seine fishery (Aqorau 2009). The VDS is an economic instrument designed to limit the fishing effort of purse seine vessels by setting a benchmark price and allocating tradable fishing days. In this way, the PNA are seeking to strengthen their position as a regional fisheries organisation by reinforcing cooperation through more effective and equitable transboundary management of tuna.

While the VDS has become an important economic mechanism to regulate fishing rights in PNA waters, its implementation remains dependent on the interests of both member states and DWFNs. This dependence in turn challenges the overall stability and effectiveness of the PNA as a 'new' form of fisheries (sub-)regionalism that can overcome the limitations of the WCPFC (Havice and Campling 2010; Havice 2013; Miller et al. 2014). PNA officials acknowledge that the effective implementation of the VDS could potentially improve economic rents and at the same time achieve sustainability objectives (Aqorau T, 2014, Chief executive officer of the PNA office. Honiara, Solomon, personal communication; Kumoru L, 2014, Executive manager-fisheries management. National Fisheries Authority, Papua New Guinea, personal communication; Pangelinan E, 2014, Deputy directornational oceanic resource management. Federated State of Micronesia, personal communication). Yet, it has proven difficult to implement a level of monitoring sufficient to achieve full compliance with VDS rules due to (pre)existing multilateral fishing access and trade agreements with major international players such as the EU and US (PNA 2014a, b, 2015a, b).

This paper analyses the present-day internal stability of the Palau Agreement by assessing the incentives each member has to either stay or leave (using data from 2014) (Pintassilgo et al. 2010; Hannesson 2011). In doing so, we examine the role of transfers from third parties like the US and EU to the PNA members to remain in or deviate from the VDS. We use the terms 'full participation' to refer to membership and 'full compliance' to refer to members' actions in accordance with the VDS. 'Partial agreement' refers to some party leaving the Nauru Agreement while others stay on, and 'partial compliance' refers to violation of VDS rules while maintaining PNA membership. The basis of our analysis is the allocation and use of VDS fishing days within agreed limits of total allowable efforts (TAEs), or sale of these days at or above a benchmark price. We determine PNA members' payoffs under partial and full compliance. In doing so, we determine how the level of VDS compliance facilitates cooperation towards strengthening the PNA as a new form of fisheries (sub-)regionalism.

The following section provides a brief account of the application of coalition theory to international fisheries agreements. We then present details of the VDS in the presence of (pre)existing tuna treaties, explain our methodology for calculating payoffs and present our results. Finally, we discuss and evaluate the wider political economic setting of (pre)existing access and trade agreements using the case of Kiribati and PNG. Kiribati and PNG are key players with the largest fishing efforts in the region and are countries who can either severely impair the agreement or foster compliance with the VDS.

\section{Internal stability of fisheries agreements}

Coalition theory (a branch of game theory) has been applied widely to analyse international environmental agreements on 


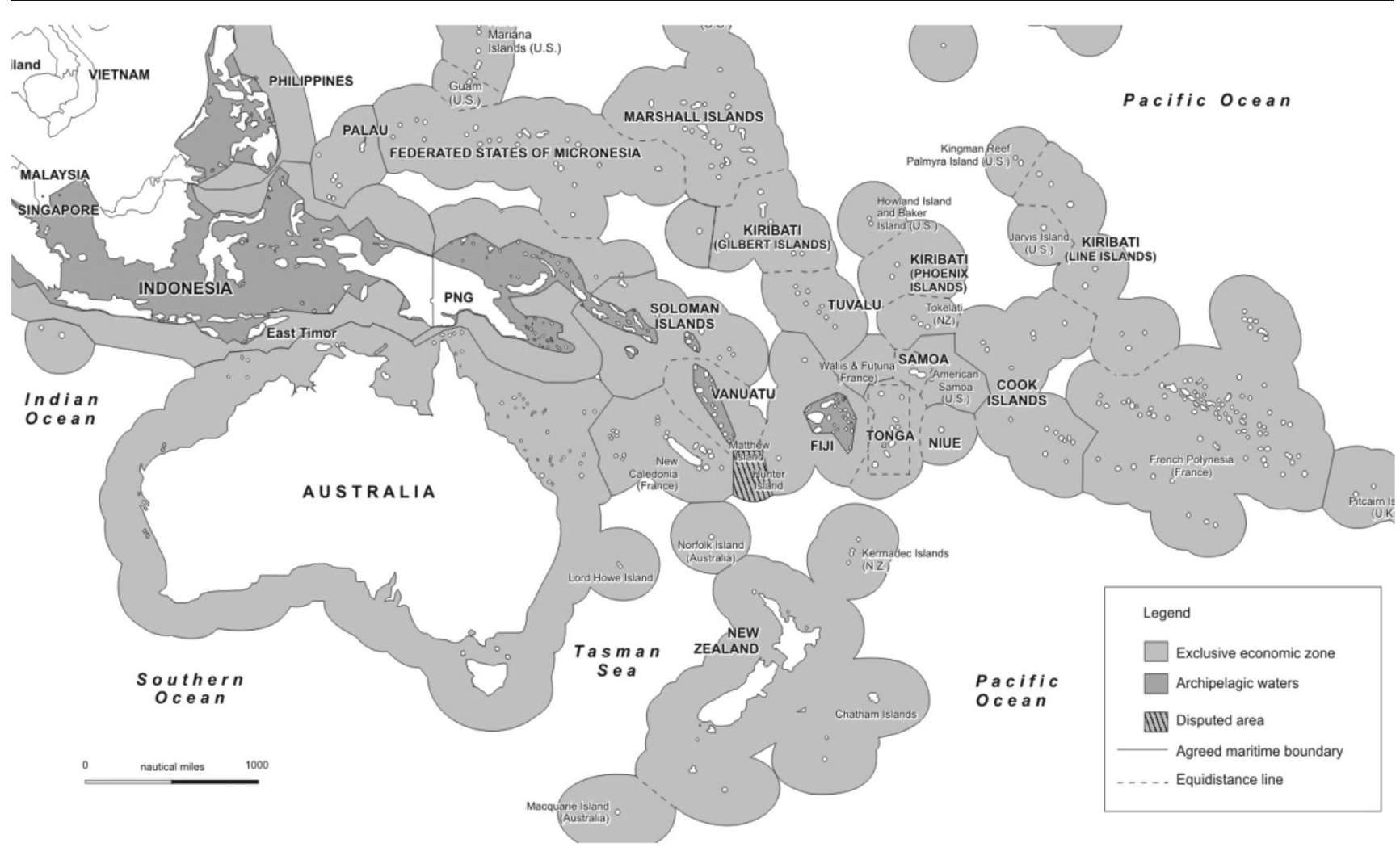

Fig. 1 Map of the Parties to the Nauru Agreement (PNA) and non-PNA countries. Source: Hanich and Ota (2013)

transboundary problems caused by externalities, such as migratory fish stocks (Bailey et al. 2010; Hannesson 2011). There is consensus in the literature on international fisheries management that countries with shared resources benefit from regional cooperation to conserve and manage those resources (Lindroos and Pintassilgo 2008; Rahikainen et al. 2008; Bailey et al. 2010; Hannesson 2011; Walker and Weikard 2016). Knowing that cooperation can be beneficial, it is important to understand the wider political context that has, in many cases, undermined the potential for cooperation in the first place. The focus of current research on international environmental agreements using coalition theory is therefore an analysis of drivers of stability of cooperation. In the literature, stability of an agreement is defined as a situation where each member of an agreement is better off than if it were to leave the agreement and to act as a free rider (internal stability), and at the same time, there is no outsider (non-member) who would be better off by joining the coalition (external stability) (Lindroos 2008; Pintassilgo et al. 2010).

Theoretical studies of international environmental agreements suggest that 'shallow' agreements, with a low level of commitment, are associated with broader participation and that shallow agreements can lead to more effective cooperation than agreements with ambitious targets and strict rules (Barrett 1994, 1998; Finus and Maus 2008). A common assumption in this literature is that deviations from international agreements occur when incentives to violate the agreement outweigh the gains from compliance (Mitchell 2007; Finus and Maus 2008; Wangler et al. 2013), or when there are loopholes in the agreement (Havice and Campling 2010; Havice 2013; PNA 2014a, b). Finus and Maus (2008) further argue that, given persistent free rider incentives, a stable coalition is not always facilitated by full compliance. Rather, members may find it beneficial to slightly deviate, and prefer this to leaving the agreement. However, it remains unclear whether this deviation will be tolerated by other members in the long term. Our study provides empirical evidence for the theoretical finding that pragmatic tolerance, i.e. allowing for less than full compliance, may stimulate participation.

\section{Data and approach}

We operationalise and apply the concept of pragmatic tolerance in a three-step approach. First, using VDS data from 2014, we analyse the Palau Agreement in the context of the multiple tuna treaties existing in the region. The different treaties do not only have separate goals and applications but may also conflict with VDS implementation. We estimate revenues from access fees based on the rules for different fleets and countries that define the uptake, monitoring and enforcement of the VDS. We calculate countries' payoffs under full and partial compliance with the rules of the VDS, taking into account transfers from third parties and their implications on 
countries' payoffs. Second, comparisons of payoffs allow us to study incentives for deviation that are inherent to (pre)existing access and trade agreements with third parties. Finally, we provide a more in-depth analysis of the two most influential countries in the PNA, namely Kiribati and Papua New Guinea, and the influence of their access and trade agreements with the European Union and the US.

Our analysis is based on information and data gathered through interviews, observations and document reviews of a number of regional fisheries meetings attended by the first author. ${ }^{1} \mathrm{~A}$ total of 22 interviews, including online communications, were conducted between 2014 and 2016 with officials from all PNA countries and experts from the PNA office, the Pacific Island Forum Fisheries Agency (FFA 2014) and industry. Qualitative and semi-structured interviews were recorded where permission was given, and notes were taken where recording was not permitted. Quantitative data - at fleet and national level - are challenging to obtain, due to confidentiality; therefore, we rely on reports that are made available in the public database domains of the WCPFC, FFA and Secretariat of the Pacific Community to calculate external incentives. We also use aggregated VDS data made available by PNA delegations and the PNA Secretariat to calculate countries' payoffs. Details of data used for calculations are provided in Supplementary materials.

\section{Implications of tuna treaties on the VDS}

\section{Tuna regimes and VDS}

The 1982 United Nations Convention on the Law of the Sea and the declaration of the 200 miles exclusive economic zone (EEZ) provide the legal framework for countries' right to manage and exploit resources within their designated zones (UNCLOS 1982). The EEZ declaration has motivated Pacific countries to build a forum to promote regional harmonisation of fisheries policies as a means to jointly manage tuna resources and provide technical advice and support for tuna access agreements (Havice 2010). However, history shows that slow progress has been made towards the effective management of both economic returns and sustainability of tuna stocks.

Prior to the VDS, access to fishing in the Pacific was regulated through bilateral and multilateral agreements with DWFNs, whereby DWFNs were allowed to fish freely in any of the Pacific waters without restriction (Havice 2010). The 1992 Palau Agreement was a first attempt to reduce purse seine fishing effort by setting a cap on the number of vessels.

\footnotetext{
${ }^{1}$ The meetings attended include the 10th and 11th regular meeting of the WCPFC, 19th and 20th meeting of the Parties to the Palau Agreement, 19th and 20th meeting of the Parties to the Federates States Micronesian Agreement, the 33rd and 34th meeting of the PNA and the 5th Pacific Tuna Forum meeting.
}

This restriction was replaced with the VDS in 2007, which further defines tradable efforts using fishing days that are allocated to member states. Introduction of the VDS was an explicit move towards rights-based fisheries management (Aqorau 2009; Havice 2013), and its implementation began in 2012, soon after a cartel-like agreement was formed in 2010 to control the benchmark price for fishing days (Havice 2010). Through the VDS, PNA members aim to create scarcity and improve fishing efficiency and economic returns to members while maintaining sustainable effort levels (currently set at the 2010 levels) (Harley et al. 2014; WCPFC 2014a, b), which is achieved through regulation of access to fishing grounds. Since its implementation, the VDS has become an integral part of the PNA's and the WCPFC's management systems. The VDS covers approximately $70 \%$ of purse seine fishing that takes place within $20^{\circ}$ north and south of the equator, covering the EEZs of the eight PNA countries (see Fig. 1).

VDS rules require members to fish within the TAE limits, or sell those days at the benchmark price (or higher) to distant water vessels under licence agreements. The minimum terms and conditions for licence agreements with foreign vessels are coordinated under the 'implementing arrangements' (PNA 2012), which require foreign vessels to be registered and licenced, report catches, maintain log books, allow observers on board and maintain transparency over their fishing activities (PNA 2010, 2016). These operational requirements form the basis for all purse seine licence agreements in the combined EEZs of the PNA member states, though the actual implementation at the country and fleet level remains key to management success.

The distribution of TAEs is coordinated and agreed by members at the PNA annual meetings (PNA 2012; Clark S, 2014, PNA consultant Honiara, Solomons. FFA, 2014, Economic indicators report October 2014 (interim). F. Development. Honiara, Solomon, FFA, personal communication). The TAEs are allocated to purse seine vessels fishing under four types of agreement: (1) the US Tuna Treaty (UST), (2) the Palau Agreement, (3) the 'joint venture and flag state arrangements' under the Federated States of Micronesia agreement (FSMA) and (4) the EU-Kiribati fisheries partnership agreement. ${ }^{2}$ Supplementary Table 1 provides a brief comparison of the different agreement types and how they differ from the Palau Agreement for VDS. Further, for TAE allocation, priority is given to the FSMA and the UST treaty (the two multilateral agreement in the Pacific), while remaining days are allocated to countries to sell to their bilateral fishing partners (Clark S, 2014, PNA consultant Honiara, Solomons. FFA, 2014, Economic indicators report October 2014 (interim). F. Development. Honiara, Solomon, FFA, personal communication; Pangelinan E, 2014, Deputy directornational oceanic resource management. Federated State of

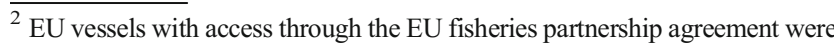
exempt from the VDS at the time of writing.
} 
Table 1 Fishing days allocation by country in the waters of the Parties to the Nauru Agreement (PNA) 2014

\begin{tabular}{|c|c|c|c|c|c|c|}
\hline $\begin{array}{l}\text { PNA } \\
\text { countries }\end{array}$ & $\begin{array}{l}\text { Total allowable effort } \\
\text { (TAEs) in days under } \mathrm{VDS}^{\mathrm{a}} \\
\mathrm{A}=\mathrm{B}+\mathrm{C}+\mathrm{D}+\mathrm{E}\end{array}$ & $\begin{array}{l}\text { Days to bilateral } \\
\text { agreements } \\
\text { B }\end{array}$ & $\begin{array}{l}\text { Days to } \mathrm{FSMA}^{\mathrm{c}} \\
\mathrm{C}\end{array}$ & $\begin{array}{l}\text { Days to } \mathrm{UST}^{\mathrm{d}} \\
\text { D }\end{array}$ & $\begin{array}{l}\text { Days in the high seas } \\
\text { E }\end{array}$ & $\begin{array}{l}\text { Days in the } \\
\text { achipelagic waters } \\
\text { F }\end{array}$ \\
\hline FSM & 6135 & 4530 & 462 & 243 & 900 & 721 \\
\hline Kiribati & 11,187 & 3499 & 627 & 4737 & 2324 & 4593 \\
\hline Marshall & 3292 & 1887 & 992 & 413 & 0 & 464 \\
\hline Nauru & 2292 & 1354 & 0 & 670 & 268 & 557 \\
\hline Palau & 510 & 495 & 0 & 0 & 15 & 123 \\
\hline PNG & 15,495 & 11,435 & 1732 & 54 & 2274 & 1079 \\
\hline Solomon & 2805 & 2466 & 0 & 11 & 328 & 80 \\
\hline Tuvalu & 1764 & 700 & 0 & 699 & 365 & 27 \\
\hline Totals & 43,480 & 26,365 & 3813 & 6827 & 6475 & 7644 \\
\hline
\end{tabular}

Source: fieldwork

a Total days in the countries' EEZ used by the three agreements and in fishing in the high seas

${ }^{\mathrm{b}}$ Adjusted 2014 total allowable efforts from VDS outcomes, extracted from report of the purse seine VDS administrator 2014 and 2015

${ }^{\mathrm{c}}$ Fishing days used by FSMA vessels in 2014, extracted from the 20th meeting of the Palau Agreement paper on purse seine VDS PAEs for 2015 to 2017

${ }^{\mathrm{d}}$ Fishing days used by US vessels in 2014, extracted from the 20th meeting of the Palau Agreement paper on purse seine VDS PAEs for 2015 to 2017

${ }^{\mathrm{e}}$ Estimated efforts in the high seas (see Supplementary material for details)

${ }^{\mathrm{f}}$ Estimated efforts in the archipelagic and days fished by EU vessels (see Supplementary material for details)

Micronesia, personal communication; Taanga A, 2014, Senior fisheries officer. Ministry of Fisheries and Marine Resources Development, The Government of Kiribati, personal communication). Table 1 provides the distribution of TAEs by country according to the three agreement types (excluding EUKiribati agreement) in 2014.

The FSMA motivates PNA members to participate in domestic fishing rather than relying on access fees alone by allowing members to enter into joint ventures and flag state arrangements with foreign companies. FSMA vessels are given concessions to fish in domestic waters at a rate of US $\$ 4000$ in 2014 as compared to the cost of fishing within the VDS area of around US\$6000 (see Supplementary Table 3.1). PNA countries realise that reduced access fees through the FSMA are undermining the Palau Agreement by undercutting the VDS benchmark price and offer additional incentives for DWFNs to increase fishing outside the VDS (PNA, 2014a, b, 2015a, b).

The UST treaty has similar implications on the VDS for two reasons. First, priority is given to the US vessels where 6827 fishing days were contributed from PNA members ${ }^{3}$ in 2014 without pre-negotiations with the member countries. Second, the price of a US fishing day is set at US $\$ 5500$, still lower than the VDS benchmark price, although the application of the VDS to US vessels resulted in improving the total value of the UST treaty to US\$63 million, which is about three times the amount that was paid by US vessels prior to VDS.

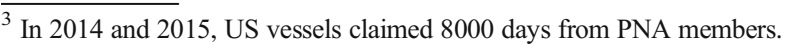

\section{Non-fishing days and high seas efforts}

Exceeding the assigned TAE under the VDS leads to an adjustment of the following year's vessel days by deducting “(i) the amount of the excess, if the excess is less than 100 days, and (ii) $120 \%$ of the excess if the excess is 100 days or more" (PNA 2012, p. 11). Although the consequences of an infringement are clear, monitoring and enforcement remains weak due to existing loopholes associated with (pre)existing legal obligations to tuna regimes in particular the UST treaty and the FSMA (Aqorau T, 2014, Chief executive officer of the PNA office. Honiara, Solomon, personal communication; Kumoru L, 2014, Executive manager-fisheries management. National Fisheries Authority, Papua New Guinea, personal communication; Pangelinan E, 2014, Deputy directornational oceanic resource management. Federated State of Micronesia, personal communication). These loopholes prevent PNA from effectively enforcing VDS rules. In practice, countries fail to consistently apply their limit on fishing days and to stop fishing when their allocations have been exhausted.

Respondents observed that under the FSMA, fishing effort in both archipelagic waters and territorial waters is counted as non-fishing days and thus not deducted from the TAEs (PNA 2015a, b). In 2013 and 2014, non-fishing days reached 8500 and 7660 days, respectively, accounting for $15 \%$ of the total days fished in PNA waters (PNA 2014a, b). We assume that the reported 7160 days in the archipelagic waters were fishing days, but the remaining 500 non-fishing days were transit days and not fished (see Supplementary Table 4). For our analysis, 


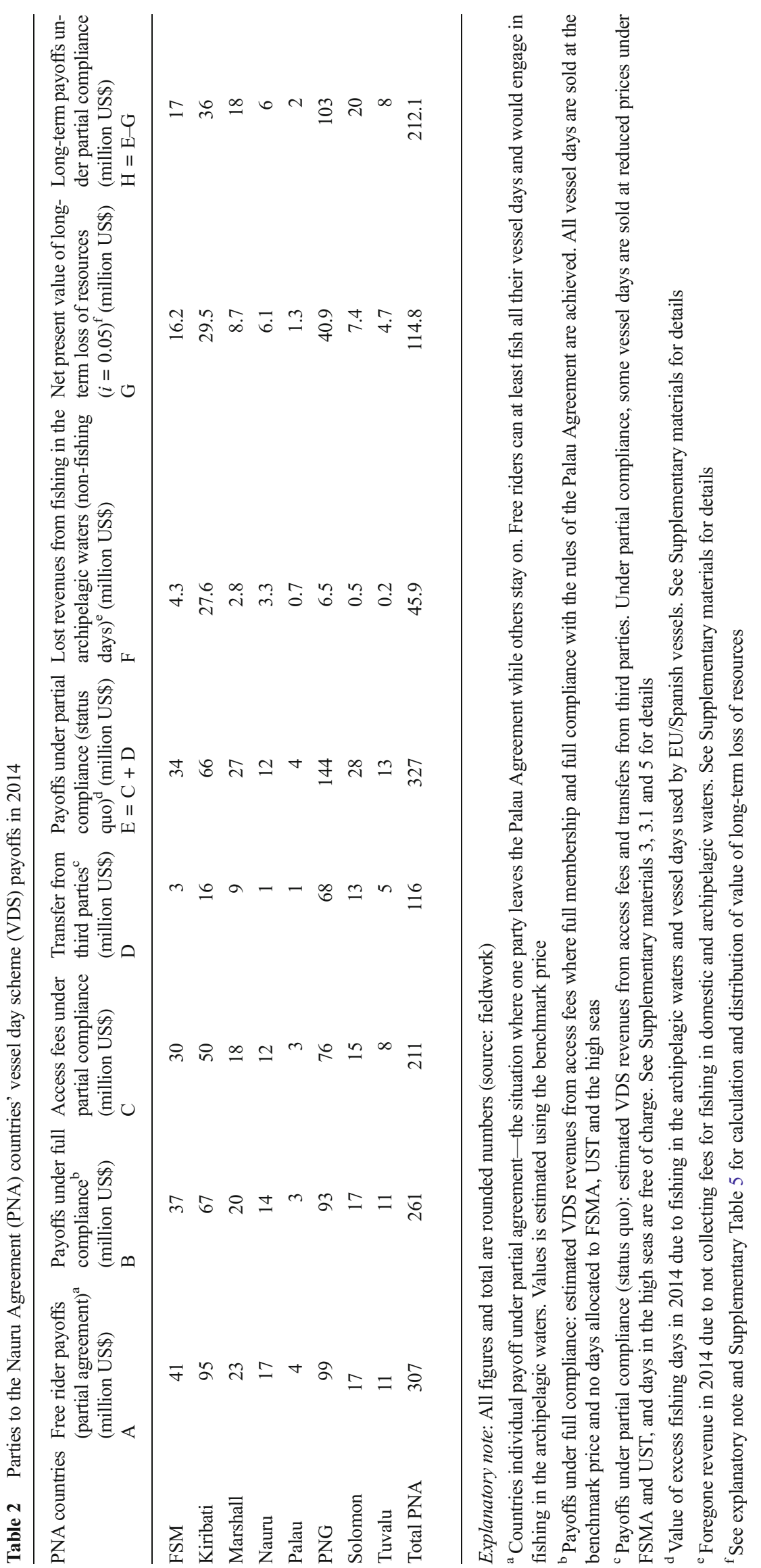


Table 3 Parties to the Nauru Agreement (PNA) countries' incentives for participation and compliance

\begin{tabular}{|c|c|c|c|c|c|}
\hline \multirow[b]{2}{*}{ PNA countries } & \multicolumn{3}{|c|}{ Incentives to participate } & \multicolumn{2}{|l|}{ Incentives to comply } \\
\hline & $\begin{array}{l}\text { Stability under full } \\
\text { compliance } \\
\text { (million US\$) } \\
\mathrm{a}=\mathrm{B}-\mathrm{A}\end{array}$ & $\begin{array}{l}\text { Short-term stability } \\
\text { under partial compliance } \\
\text { (million US\$) } \\
\mathrm{b}=\mathrm{E}-\mathrm{A}\end{array}$ & $\begin{array}{l}\text { Long-term stability } \\
\text { under partial compliance } \\
\text { (million US\$) } \\
\mathrm{c}=(\mathrm{E}-\mathrm{G} 5)-\mathrm{A}\end{array}$ & $\begin{array}{l}\text { Short-term incentive to } \\
\text { deviate from full compliance } \\
\text { (million US\$) } \\
\mathrm{d}=\mathrm{E}-\mathrm{B}\end{array}$ & $\begin{array}{l}\text { Long-term incentive to } \\
\text { deviate from full compliance } \\
\text { (million US\$) } \\
\mathrm{e}=(\mathrm{E}-\mathrm{G} 5)-\mathrm{B}\end{array}$ \\
\hline FSM & -4 & -7 & -24 & -3 & -19 \\
\hline Kiribati & -28 & -29 & -58 & -1 & -31 \\
\hline Marshall & -3 & 4 & -4 & 7 & -1 \\
\hline Nauru & -3 & -5 & -11 & -1 & -7 \\
\hline Palau & -1 & 0 & -1 & 1 & -1 \\
\hline PNG & -6 & 44 & 3 & 51 & 10 \\
\hline Solomon & 0 & 10 & 3 & 11 & 3 \\
\hline Tuvalu & 0 & 2 & -2 & 3 & -2 \\
\hline Total PNA & -46 & 20 & -95 & 66 & -49 \\
\hline
\end{tabular}

Explanatory notes: Table 3 is linked to the columns in Table 2. See Supplementary Table 5 for $i=5 \%$ and $i=10 \%$. All figures and total are rounded numbers. Countries with 0 incentives in fact are having small negative incentives rounded to 0 (source: fieldwork)

we define excess efforts as days fished reported as non-fishing days in the archipelagic waters plus the days fished by EU/ Spanish vessels which were not deducted from the Kiribati TAEs, giving 7644 non-fishing days in 2014 (Table 1 column F, and Supplementary Table 4 for details). Assuming that TAEs reflect a sustainable effort level, we consider this excess effort as overfishing, implying that they will reduce future stocks. We refer to the reduction of stock as lost resources and include it in the calculation of long-term incentives to deviate from full compliance (Table 2, column G, see also the Appendix in the Supplementary material).

Fishing effort in the eastern high seas of Kiribati and the high seas pockets of Tuvalu, Fiji and Kiribati is treated under WCPFC exemptions for Small Island Developing States (SIDs). The SIDs exemption is designed to protect these states from a disproportionate burden from WCPFC effort limits in the high seas. The WCPFC measures for bigeye and yellowfin consider especially the geo-political heterogeneity of SIDs, which are made up of noncontiguous groups of islands having a distinct economic and cultural identity due to separation by areas of high seas (see Fig. 1) (WCPFC 2014). Using high seas aggregated data, we estimate the distribution of high seas efforts by countries based on the fishing location in the high seas and countries shares of TAEs (see in Supplementary Table 6). Our estimate shows that about 6475 days are distributed and deducted from the TAEs (see Table 1, column E), but no revenues flow to PNA members for fishing days in the high seas. Revenues from access fees under partial compliance therefore comprise of UST revenues, FSMA revenues and revenues from bilateral agreements (see Supplementary Table 3 for details).

\section{Incentives for compliance}

We analyse the stability of the Palau Agreement by looking at the incentives set by the various external agreements to deviate from full compliance with VDS rules. The countries (players of the game) are the Parties to the Palau Agreement ${ }^{4}$ and we label the set of players as $N$, where a typical country is labelled $i \in N$. Country $i$ has a total allowable effort measured in days, $\bar{d}_{i}$, that are sold under different types of agreements, $a$, with different prices for the VDS benchmark price $\left(p_{\mathrm{vds}}\right)$ applicable under the bilateral agreements, ${ }^{5}$ the Federated States of Micronesia Agreement $\left(p_{\mathrm{fsm}}\right)$, the US treaty $\left(p_{\text {us }}\right)$ and the EU-Kiribati Fisheries Partnership Agreement $\left(p_{\mathrm{eu}}\right)$. No revenues are collected for days fished in the high seas $\left(p_{\mathrm{hs}}=0\right)$, but these days are deducted from the TAEs. The set of agreements is labelled as $A=\{\mathrm{vds}, \mathrm{fsm}, \mathrm{us}, \mathrm{eu}, \mathrm{hs}\}$. The total allowable effort (fishing days) for country $i$ is allocated to the different agreements, see Supplementary Table 3.1

$\bar{d}_{i} \geq d_{i} \equiv \sum_{a \in A} d_{i, a}$

The payoff of country $i$, for all $i \in N$, is therefore given by:

$\Pi_{i}=\sum_{a \in A} d_{i, a} \cdot p_{a}$

The stability of the Palau Agreement is dependent on the preference to stay in the coalition as opposed to leaving the coalition

\footnotetext{
${ }^{4}$ Tokelau is a member of the Palau Agreement but is not included in the payoff calculation given it is not a PNA member and accounts only for a small number of fishing days, see Supplementary Table 3.1.

${ }^{5}$ We use vds as notation for bilateral agreements as they strictly apply VDS.
} 
(i.e. free riding). We construct scenarios to compare the payoffs when countries fully comply with VDS rules and the payoffs under partial compliance. Full compliance with VDS means that all conditions of the Palau Agreement are met. The conditions include limiting effort within the total allowable effort (fishing days) and selling fishing days at or above the agreed benchmark price (PNA 2012). We assume full compliance when, $d_{i, \mathrm{fsm}}=d_{i \text {, us }}=d_{i \text {, eu }}=d_{i \text {, hs }}=0$, i.e. when $d_{i \text {, vds }}=\bar{d}_{i}$. Partial compliance is when fishing days are allocated to agreements where the VDS benchmark price is undercut, i.e. $d_{i, \text { fsm }}+$ $d_{i, \text { us }}+d_{i, \text { eu }}+d_{i, \text { hs }}>0$, or when countries fail to close their waters when their days are exhausted, i.e. $d_{i}>\bar{d}_{i}$.

Days fished in domestic and archipelagic waters are reported

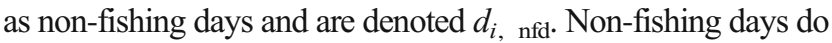
not just mean foregone revenues from access fees in a given year but also represent fishing efforts beyond sustainable levels (i.e. above and beyond the TAE) and therefore a loss of resources for future use. We calculate the value of forgone revenues due to overfishing $\left(d_{i, \mathrm{nfd}} \cdot p_{\mathrm{vds}}\right)$ and estimate the impact of overfishing on the future sustainable (steady state) catch. To assess the latter, we use a Gordon-Schaefer model (see Supplementary material) and find that excess fishing of $15 \%$ beyond sustainable yields is associated with a reduction in sustainable harvests of about $2.2 \%$. This implies a loss of 957 fishing days to be subtracted from future TAEs. Assuming a discount rate of 5\%, we estimate the value of lost resources due to overfishing (Table 2, column G); for details, see Supplementary Table 3 and the explanatory note in Supplementary material.

\section{Payoffs under partial and full compliance}

In order to assess the stability of the Palau Agreement and the incentives for VDS compliance, we estimate the following: (1) free rider payoffs, (2) VDS revenues from access fees for all PNA countries, (3) payoffs under full and partial compliance, (4) transfer payments received, (5) lost revenues and (6) lost resources due to overfishing (Table 2). We assume that free riders engage in overfishing and, in doing so, can at least fish all their vessel days and engage in fishing in the archipelagic waters. Using the vessel days allocation and non-fishing days data (Table 1), free rider payoffs for individual countries are larger than their payoffs under full compliance (Tables 2 and 3). We conclude that with strict enforcement and full compliance to VDS rules, the Palau Agreement would be unstable. Our results also indicate that under partial VDS compliance, the Palau Agreement would only be stable in the short term but not in the long term (Table 3, columns b and c).

We also observe that partial compliance is preferred to full compliance in the short term by a number of countries, including Marshall Islands, Palau, PNG, Solomon Islands and Tuvalu (see Table 3, column d). However, these payoff calculations do not account for lost revenues and lost resources from the allocation of fishing effort in domestic and archipelagic waters as non-fishing days (see Table 2, columns F and G). The results indicate that from a longer term perspective, it does not pay to overfish even if revenues for non-fishing days were collected (which is not the case) (comparing Table 2, columns F and G). This holds even if we use a high discount rate of $10 \%$ and the result is strengthened when applying lower discount rates (see Supplementary Table 5).

Overall, we estimate that lost resources due to overfishing amount to about US\$115 million assuming a 5\% discount rate (Table 2). The results also show that the members of the PNA allow fishing outside the VDS area because transfers received from third parties are high enough to compensate for the lost revenues from forgone days. However, when potential future lost resources are considered, these payments are not enough to offset the externalities produced by the allocation of 'nonfishing days'. As shown in Table 2 (column $\mathrm{H}$ ) and Table 3 (column e), with a long-term perspective to management full compliance is the best option. In this case, the only countries with an incentive to deviate from full compliance are PNG and Solomon because of their interests and participation in domestic fishing. Domestic fishing allows for fishing outside the countries' EEZs and is therefore accounted for as 'non-fishing days'.

Transfers from third parties include dividends from joint venture fishing companies, benefits from employment and grants for fisheries-related development under the (pre)existing treaties (see Table 2, column D). ${ }^{6}$ The PNA's joint benefits from these transfers in 2014 are around US\$116 million, of which about $60 \%$ is received by PNG. From the Palau Agreement's point of view, these benefits, however, come at the cost of lost revenues and excess efforts undermining the VDS rules due to concessions and reduced rates. ${ }^{7}$

Transfers from third parties offer an opportunity to look at the political challenges of why VDS cannot be fully implemented. Our payoff results indicate that the VDS implementation suffers from individual countries' taking short-term gains offered through the (pre)existing access agreements at the expense of the long-term collective sustainability goals. The result indicates that the incentives are large enough to compensate for loss of revenues and lost resources from forgone fishing days, i.e. US $\$ 116$ million compared to US $\$ 84.5$ million ${ }^{8}$ currently. Hence, overall, countries still have some incentives to deviate from full compliance with the VDS rules. This means that the transfers from bilateral contracts disincentivise full VDS compliance in the short term. On the assumption that TAEs are set optimally, the lenient

\footnotetext{
${ }^{6}$ See Supplementary Table 2 for transfers from third parties calculation and Supplementary Tables 2.1 to 2.4 for raw and secondary data used for calculations.

${ }^{7}$ See the details discussed earlier in section 'Implications of tuna treaties on the VDS'.

${ }^{8}$ Total lost resources from fishing outside the VDS area, i.e. US\$45.86 million (Table 2, column F) and US\$38.9 million (6475 high seas efforts * US\$6000).
} 
implementation of the VDS implies that fewer resources will be available in the future.

Although it appears that PNA countries prefer partial compliance to full compliance in the short term due to the transfers received, this is not the case when countries adopt a long-term perspective. Over the long term, partial compliance leads to overfishing and lower TAEs. The value of the resources lost due to overfishing (Table 2, column $\mathrm{G}$ ) is very sensitive to the discount rate. Assuming a 5\% discount rate, long-term payoffs under partial compliance are less than under full compliance (Table 2, column H). Only at very high discount rates (exceeding $8.7 \%$ ) do PNA members have an incentive to maintain the status quo of partial compliance.

However, at the country level, three of the PNA members, i.e. FSM, Kiribati and Nauru, have negative incentives to deviate from full compliance in both the short term and long term. ${ }^{9}$ The negative incentives indicate that these countries depend on revenues from access fees, and would therefore be worse off through violation of the VDS. This is because their benefits from transfers are not high enough to compensate for the cost of partial compliance. This is also true assuming a $10 \%$ discount rate (see Supplementary Table 5). Assuming a 5\% discount rate, however, the collective advantage of full compliance amounts to US\$49 million compared to partial compliance (Table 3, column e).

In summary, the results provide empirical support of Finus and Maus (2008), who theoretically argue that partial compliance or pragmatic tolerance provides incentives for countries to remain in a coalition. This indicates that while PNA cooperation may not appear rational today, it is rational to cooperate for benefits in the future. It also means that prescribing full cooperation today may cause a breakdown of the PNA if countries are myopic and give little weight to future gains of cooperation. Allowing slight deviations, pragmatic tolerance, may be an appropriate means of maintaining the coalition. The Nauru Agreement is therefore potentially internally stable under partial compliance with the VDS, although we acknowledge that individual countries still seem to have an incentive to leave. Full compliance is the first best outcome as revenue from access fees are greater than they are under partial compliance, but only if there are no incentives to deviate from full compliance. The presence of free rider incentives is then likely to make the Palau Agreement internally unstable. Therefore, partial compliance with VDS rules or pragmatic tolerance with deviation facilitates full participation in the Palau Agreement.

\footnotetext{
${ }^{9}$ Six countries are having negative incentives to deviate from full compliance when considering the long term.
}

\section{Case analysis-PNG and Kiribati}

To further understand the role of transfers from third parties in stabilising the Nauru Agreement under partial compliance, we now turn our attention to PNG and Kiribati. Both countries are central to the implementation of the VDS given they have the largest share of both fishing effort and catch within the PNA. As dominant players, they also play the most important role in the overall stability of the VDS and therefore the success of new fisheries regionalism. They are also particularly interesting for our analysis because, based on the 2014 data, both Kiribati and PNG have the most non-fishing days at 4593 and 1074 days, respectively (see Table 1). Furthermore, both countries are firmly engaged in (pre)existing access and trade agreements with, amongst others, the European Union. We now provide a more detailed account on the influence of both countries on the stability of the VDS.

\section{Papua New Guinea}

The analysis of payoffs indicates that PNG is better off with partial compliance rather than with full compliance under the status quo (Table 2). Specifically, PNG's estimated revenue from access fees under partial compliance is around US\$76 million compared to US\$93 million under full compliance (see Table 2, columns C and B). However, PNG gains about US\$68 million as transfers from third parties under partial compliance, making PNG's current payoff under the status quo to be around US\$144 million.

Transfers from third parties include grants and associated benefits from access agreements under the UST treaty and the FSMA. The UST treaty allocates at least US $\$ 0.5$ million annually to each Pacific Island country in addition to any access fees (for details, see Supplementary Materials). The distribution of FSMA grants is negotiated and decided bilaterally between the PNG government and foreign firms. However, the FSMA countries tolerate the high rate of 'non-fishing days' in the archipelagic waters - of which PNG has the largest area. Based on non-fishing days data, we estimate the value of lost resources to PNG at around US\$41 million (Table 2, column G). But this estimate also shows that PNG's long-term payoff under partial compliance is still preferred to full compliance. Therefore, in the case of PNG, we see a role for pragmatic tolerance even in the long term. PNG is better off as member than as a free rider, but this would not be true for full compliance. Also note that PNG's short-term incentive to deviate from full compliance is stronger than its long-term incentive.

According to Hamilton et al. (2011), the EU interim economic partnership agreement that allows duty free access to the EU markets for PNG is also a factor undermining the VDS. The concern was that distant water fishing nations investing in processing capacity in PNG to gain access to 
FSMA flagged vessels will increase the overall fishing capacity in archipelagic waters. However, the EU interim agreement has since forced PNG to improve the application and enforcement of the VDS, with specific attention being given to the declaration of non-fishing days in the archipelagic waters (Atuna 2015). Failure to do so could jeopardise about US\$60 million in employment benefits if conditional access of PNG processing plants to the EU market was lost. Respondents argue that although PNG has addressed nonfishing days in 2015 , by enforcing VDS in the archipelagic and territorial waters, the VDS price remains an issue. Our results indicate that addressing non-fishing days will reduce PNG's lost resources from excess efforts (Table 2, column G), but could potentially improve long-term payoffs. It therefore appears that addressing non-fishing days can present a positive incentive for long-term resource stewardship, which also supports our claim that longer term gains can be realised by addressing compliance issues of the VDS.

\section{Kiribati}

Our results indicate that Kiribati is better off under full rather than partial compliance with the VDS. Based on available data, Kiribati is currently earning about US\$50 million under partial compliance compared to US\$67 million should strict application of the VDS rules be applied (Table 2). Like PNG, Kiribati also bears the highest loss of revenues for high seas fishing given their share of efforts in the high seas. However, an additional US\$16 million in transfers from third parties increases the total payoff for partial compliance to US\$66 million. These calculations highlight that the US\$1 million shortfall under partial compliance should incentivise Kiribati to support full VDS compliance.

Transfers from third parties to Kiribati are contributed from grants and payments associated with the UST treaty, FSMA and the EU-Kiribati fisheries partnership agreement. While these transfers appear to offer some incentive for Kiribati to allocate part of its TAE to the high seas in support of its domestic or joint venture partners, they do not appear large enough to compensate for both current lost revenues and loss of resources. Based on the 2014 data, Kiribati contributed the largest share of fishing effort of all PNA members outside the VDS. Assuming a 5\% discount rate, we estimate that this allocation leads to a US\$30 million loss in future resources for Kiribati. It therefore appears that the benefits from transfers are not large enough to compensate for Kiribati's losses from fishing outside the VDS (Table 2, column H). Table 1 shows that Kiribati is the biggest defector with the highest share of fishing outside the VDS. Therefore, it also suffers the largest losses of revenues. For this reason, our result suggests that Kiribati is better off under fully enforced VDS rules given this will increase payoffs in both the short and long term (Table 3, columns d and e). Second, our result suggests that while
Kiribati enforces VDS rules in the high seas by deducting TAEs, they could also improve benefits by engaging in domestic fishing and processing like PNG. A similar analysis also applies to other countries with negative incentives to deviate from full compliance, in particular FSM and Nauru.

In contrast to PNG, the EU agreement with Kiribati appears to undermine the VDS. Kiribati has exempted the EU's (mostly Spanish) purse seine vessels from the VDS and agreed to a vessel day rate of US\$2207 in return for US\$8 million in aid from the EU. It appears that in doing so Kiribati is accepting short-term over long-term benefits. Including fishing efforts by the EU vessels as non-fishing days leads to both lost revenues (Table 2, column F) and a loss of resources (Table 2, column G). After facing increased pressure from within the PNA to consistently apply VDS across all vessels, Kiribati began applying the VDS to the Spanish vessels in 2015 . Because the EU did not agree to the terms of the VDS, the EU-Kiribati fisheries partnership agreement has been suspended. At the time of writing, Spanish vessels have left the Kiribati waters and are entering into a new fisheries agreement with Cook Islands. Though these latest changes are not included in our analysis, the suspension of EU-Kiribati fisheries partnership will result in short-term economic losses from reduced access payments for Spanish vessels. But in the long term, Kiribati will gain by mitigating the future loss of resources (Table 2, column G) and will eventually improve the incentives for full compliance (Table 3, column e).

\section{Implications for fisheries regionalism}

Our analysis demonstrates the challenges of full VDS compliance by the PNA countries in the presence of free rider incentives. In doing so, we provide insights in how the stability of the PNA as a 'new fisheries sub-region' adjacent to the wider WCPFC is maintained. Our empirical application supports the notion that players are better off under full cooperation in the long term (Kronbak and Lindroos 2006; Bailey et al. 2013), but full cooperation only appears to be more beneficial in the absence of free rider incentives derived from (pre)existing access agreements. As a result, incomplete compliance emerges as the more rational option in the short term. The results also indicate that full participation is not always stable (Wangler et al. 2013). In support of Finus and Maus (2008), we show that stability of coalitions can be improved when partial compliance to the VDS is tolerated by coalition members. This is what we call 'pragmatic tolerance'. We find that a stable coalition is maintained as long as members' payoffs improve marginally beyond free rider payoffs.

The results also clearly point to the importance of the transfers from third parties to countries' economic gains. In summary, without transfers from third parties, our results indicate that payoffs from participation are better with full compliance- 
which corresponds to the theoretically ideal situation and future goal. The role of these transfers in dis-incentivising compliance to the VDS opens up wider questions around the political economy of fisheries agreements and their implications for the success of fisheries regionalism. In our case, we observe that both violations and pragmatic tolerance to partial compliance with the VDS are strongly influenced by agreements with (and in favour of) distant water fishing nations. As such, the design and implementation of the VDS cannot be seen in isolation from the dynamic and complex nature of the underlying political pressure of the DWFNs gaining and maintaining access to tuna resources (e.g. Havice 2010; Parris 2010; Campling and Havice 2012). Understanding these political dynamics helps us to better understand the internal dynamics of tolerance in ensuring the ongoing stability of an international agreement (Finus and Maus 2008; Wangler et al. 2013). As this study shows, the current levels of compensation for tolerating partial compliance may not be sustainable over the long term given that tolerance today may have negative impacts on future stocks, thus threatening sustainable tuna catches.

The specific cases of PNG and Kiribati further demonstrate how the decisions of member states are largely based on shortterm gains, even though they would be better off under full compliance over the long term. Despite criticisms of myopic decision-making (Chwe 1994; Walker and Weikard 2016), the results do indicate that countries are aware of the long-term value of the resource derived from full VDS compliance. It is therefore plausible that countries can be incentivised to remove loopholes in the VDS relating to the allocation and accounting of non-fishing days and the alignment of access fees under different access agreements to the VDS benchmark price. Progress is indeed already seen in this direction. PNG has reduced the number of non-fishing days in response to the EU interim agreement. If such incentives for trade could be extended to other PNA members' non-compliance issues, a new set of incentives may be developed to resolve these issues. Kiribati, despite facing short-term loss, has chosen to enforce the VDS at the expense of a (pre)existing agreement with the EU, particularly the Spanish vessels. Both moves by PNG and Kiribati have improved the overall governance and transparency not only within PNA but also between PNA members and DWFNs.

Building on earlier observations, our results indicate that economic institutions like the VDS can strengthen forms of fisheries sub-regionalism like the PNA (Miller et al. 2014; Yeeting et al. 2016). This paper adds to this observation by demonstrating that economic institutions can also play a key role in strengthening the political stability of these regional coalitions. But in support of Havice and Campling (2010), we also demonstrate that economic institutions are by no means isolated from the interests of powerful distant water fishing nations. Nevertheless, the VDS has re-opened the negotiation of (pre)existing access agreements with a view to apply consistent measures across all purse seine vessels in the PNA waters and also the possibility of negotiating improved conditions beyond the PNA. In effect, PNA members have been able to improve their bargaining position for better economic gains from the treaties, not only in increasing economic returns but also in developing clear limits and restrictions on fishing effort. The move towards consistent application of purse seine management across all purse seine vessels in the PNA waters has significantly improved transparency and better coordination of fishing access.

\section{Conclusion}

Our analysis provides two significant contributions to the study of international fisheries agreements. First, pragmatic tolerance of small deviations, and therefore short-term partial compliance, can be an important stepping stone in moving towards full cooperation. In light of this finding, and similar to discussions around shallow agreements, full participation in international agreements on shared resources may be improved if some flexibility is allowed. Second, countries that receive greater benefits from transfers than the value of lost resources have incentives to support pragmatic tolerance, whereas members with less benefit from transfers have no incentive to give away their fishing days for free or at a low price. Once transfers are removed, countries are likely to push for full VDS compliance rules in order to maximise their potential gains from full cooperation.

These findings hold consequences for the design of new forms of fisheries (sub-)regionalism at scales both at and below the level of regional fisheries organisations like the WCPFC. If economic institutions like the VDS offer a requisite level of incentive to members to fully cooperate, they can directly influence politically motivated side payments or transfers that have historically obstructed the success and effectiveness of sub-regional cooperation for sustainability. Said differently, such economic institutions can provide a means of addressing inefficiencies by strengthening the de facto political power of resource managers to renegotiate and restructure institutions and incentives. Further research could focus on comparative analyses at different scales and in different regions, including other regional fisheries organisations or other international regimes. Doing so would provide a more rigorous understanding of the economic and political linkages between states and their role in structuring region-building based on the stewardship of valuable and contested natural resources.

Acknowledgements The authors would like to thank the PNA office and a number of individual Senior Fisheries officials for providing data. Also, they would like to thank the two anonymous reviewers for helpful comments on earlier drafts of this paper.

Funding information This research was generously funded by Wageningen University's Interdisciplinary Research and Education 
Fund (INREF) in collaboration with the University of the South Pacific Graduate Assistant Scholarship.

Open Access This article is distributed under the terms of the Creative Commons Attribution 4.0 International License (http:// creativecommons.org/licenses/by/4.0/), which permits unrestricted use, distribution, and reproduction in any medium, provided you give appropriate credit to the original author(s) and the source, provide a link to the Creative Commons license, and indicate if changes were made.

\section{References}

Aqorau T (2006) Moving towards right based fisheries management regime for the tuna fisheries in the Western and Central Pacific Ocean. Sharing the Fish Conference, Perth, Western Australia

Aqorau T (2009) Recent developments in Pacific tuna fisheries: the Palau Arrangement and the vessel day scheme. Int J Mar Coast Law 24(3): 557-581. https://doi.org/10.1163/157180809X455647

Atuna (2015) PNG opposition supports stop to raw material exports. Atuna news. Atuna.com, Atuna

Bailey M, Rashid Sumaila U, Lindroos M (2010) Application of game theory to fisheries over three decades. Fish Res 102:1-8 https://doi.org/10.1016/j.fishres.2009.11.003

Bailey M, Rashid Sumaila U, Steven J, Martell D (2013) Can cooperative management of tuna fisheries in the Western Pacific solve the growth overfishing problem? Strategic Behav Environ 3:31-66. https://doi.org/10.1561/102.00000023

Barrett S (1994) Self-enforcing international environmental agreements. Oxf Econ Pap 46:878-894

Barrett S (1998) On the theory and diplomacy of environmental treatymaking. Environ Resour Econ 11:317-333. https://doi.org/10.1023/ A: 1008243528330

Chwe M (1994) Farshighted coalitional stability. J Econ Theory 63(2): 299-235. https://doi.org/10.1006/jeth.1994.1044

FFA (2014). Economic indicators report October 2014 (interim). Fisheries Development. Honiara, Solomon, FFA.

Finus M, Maus S (2008) Modesty may pay! J Public Econ Theory 10(5): 801-826. https://doi.org/10.1111/j.1467-9779.2008.00387.x

Gochhayat A (2014) Regionalism and sub-regionalsm: a theoretical framework with special reference to India. Afr J Polit Sci Int Relat 8(1):10-26. https://doi.org/10.5897/AJPSIR2013.0611

Hamilton A, et al. (2011). Report on the Implementation of the derogation to the standard rules of origin granted to the Pacific ACP States in the framework of the Interim Economic Partnership Agreement. Brussels, European Union. FWC COM 2011 RFS 2011/266449

Hanich Q, Ota Y (2013) Moving beyond rights-based management?: a transparent approach to distributing the conservation burden and benefit in tuna fisheries. Int J Mar Coast Law 28:135-170. https:// doi.org/10.1163/15718085-12341268

Hanich Q, Campbell B, Bailey M, Molenaar E (2010) Sovereignty and cooperation in regional Pacific tuna fisheries management: politics, economics, conservation and the vessel day scheme. Aust J Marit Ocean Aff 2(1):2-15 https://doi.org/10.1080/18366503.2010. 10815650

Hannesson R (2011) Game theory and fisheries. Ann Rev Resour Econ 3(1):181-202. https://doi.org/10.1146/annurev-resource083110-120107

Harley S, Davies N, Hampton J, McKechnie S (2014) Stock assessment of bigeye tuna in the Western and Central Pacific Ocean. Scientific committee - tenth regular session. Majuro, Marshall Islands, Western and Central Pacific Fisheries Commission. WCPFCSC10-2014/SA-WP-01

Harley S, et al. (2015) The Western and Central Pacific tuna fishery: 2013 overview and status of stocks. New Caledonia., Secretariat of the Pacific Community. Report no. 14
Havice E (2010) The structure of tuna access agreements in the Western and Central Pacific Ocean: lessons for vessel day scheme planning. Mar Policy 34. https://doi.org/10.1016/j.marpol.2010.02.004

Havice E (2013) Rights-based management in the Western and Central Pacific Ocean tuna fishery: Economic and environmental change under the vessel day scheme. Mar Policy 42:259-267. https://doi. org/10.1016/j.marpol.2013.03.003

Havice E, Campling L (2010) Shifting tides in the Western and Central Pacific Ocean tuna fishery: the political economy of regulation and industry responses. Global Environ Polit 10(1):89-114. https://doi. org/10.1162/glep.2010.10.1.89

Hegland T, Ounanian K, Raakjær J (2012) Why and how to regionalise the Common Fisheries Policy. Maritime Studies 11(1):1-21. https:// doi.org/10.1186/2212-9790-11-7

Hughes A (2005) Strengthening regional management. A review of the achitecture for regional co-operation in the Pacific. Report to the Pacific Islands Forum Report

Kronbak LG, Lindroos M (2006) An enforcement-coalition model: fishermen and authorities forming coalitions. Environ Resour Econ 35(3):169-194. https://doi.org/10.1007/s10640-006-9012-4

Langley A, Wright A, Hurry G, Hampton J, Aqorua T, Rodwell L (2009) Slow steps towards management of the world's largest tuna fishery. Mar Policy 33(2):271-279. https://doi.org/10.1016/j.marpol.2008. 07.009

Lindroos M (2008) Coalitions in international fisheries management. Nat Resour Model 21(3):366-384. https://doi.org/10.1111/j.1939-7445. 2008.00016.x

Lindroos M, Pintassilgo P (2008) Coalition formation in straddling stock fisheries: a partition function approach. Int Game Theory Rev 10(03):303-317. https://doi.org/10.1142/S0219198908001959

Miller AM, Bush R S, van Zwieten PA (2014) Sub-regionalisation of fisheries governance: the case of the Western and Central Pacific Ocean tuna fisheries. Maritime Studies 13(1):1-20. https://doi.org/10.1186/s40152-014-0017-2

Mitchell R (2007) Compliance theory: compliance, effectiveness, and behavior change in international environmental law. Oxford handbook of international environmental law. J. Brunee, D. Bodansky and E. Hey. Oxford, Oxford University Press: 893-921. doi: https://doi.org/10.1093/oxfordhb/ 9780199552153.013.0039

Pintassilgo P, Finus M, Lindroos M, Munro G (2010) Stability and success of regional fisheries management organizations. Environ Res Econ 46(3):377-402. https://doi.org/10.1007/s10640-0109346-9

PNA (2010) (As amended 11th September 2010). A third arrangement implemetating the nauru agreement setting forth additional terms and conditions of access to the fisheries zones of the parties. Majuro, PNA

PNA (2012). Palau arrangement for the management of the Western Pacific fishery as amended - management scheme (purse seine vessel day scheme) - amended 27 April 2012

PNA (2014a) PAEs for 2014, 2014 and 2016 for purse seine VDS. Parties to the Palau Arrangement. Honiara, Solomon Islands, PNA

PNA (2014b) Review of the purse seine vessel day scheme. PNA Office, Marshall Islands, PNA

PNA (2015a) Parties to the Palau Agreement: report of purse seine VDS administrator. Parties to the Palau Agreement. Yap, FSM, PNA. PA20/WP.3

PNA (2015b) Report of the FSM arrangement administrator. Parties to the FSM Arrangment. PNA. Yap, Federated States of Micronesia, PNA. FSMA20/WP/1

PNA (2016) Annual review of the 3IA. Parties to the Nauru Agreement: 35th annual meeting. Tarawa, Kiribati, PNA

Rahikainen M, et al. (2008) Stability of international fisheries agreements using precautionary bioeconomic harvesting strategies: impacts of harvesting rule on fisheries agreements. Discussion 
papers no: 27, University of Helsinki:1-44. doi:https://doi.org/ $10.1561 / 102.00000025$

Tsamenyi M, et al. (2001) International legal regime for fisheries management. Reykjavik conference on responsible fisheries in the marine ecosystem. University of Wollongong, Reykjavik, Iceland

Tsamenyi M, et al. (2004) The international legal regime for fisheries management: paper presented at the UNEP workshop on fisheries subsidies and sustainable fisheries management, University of Wollongong

UNCLOS (1982) United Nations convention on the Law of the Sea.

Walker AN, Weikard H (2016) Farsightedness, changing stock location and the stability of international fisheries agreements. Environ Resour Econ 63:591-611. https://doi.org/10.1007/ s10640-014-9853-1

Wangler L, Altamirano-Cabrera J-C, Weikard H-P (2013). The political economy of international environmental agreements: a survey.
International Environmental Agreements: Law, Politics and Economics 13: 387-403. doi: https://doi.org/10.1007/s10784-0129196-8

WCPFC (2014a) Conservation and management measure for bigeye, yellowfin and skipjack tuna in the Western and Central Pacific Ocean. 11th Regular meeting of the WCPFC. Apia, Samoa, WCPFC. Conservation and management measure 2014-01

WCPFC (2014b) Summary report : scientific committee tenth regular session. Commission for the Conservation and Management of highly migratory fish stocks in the Western and Central Pacific Ocean. Majuro, Marshall Islands, Western and Central Pacific Fisheries Commission: 1-224

Yeeting AD, Bush SR, Ram-Bidesi V, Bailey M, (2016) Implications of new economic policy instruments for tuna management in the Western and Central Pacific. Mar Policy 63:45-52 https://doi.org/ 10.1016/j.marpol.2015.10.003 